\title{
ARTYKUŁY
}

\author{
Agnieszka Bartnik (D)
}

Uniwersytet Śląski, Katowice

\section{KILKA UWAG W KWESTII IDENTYFIKACJI I LECZENIA CHORÓB OWIEC W STAROŻYTNYM RZYMIE}

\author{
Abstract \\ SOME REMARKS ON THE IDENTIFICATION AND TREATMENT \\ OF SHEEP DISEASES IN ANCIENT ROME
}

Ancient vets were giving much attention to sheep diseases. By analysing the records of ancient authors, it is possible to identify diseases attacking herds the most frequently. The greatest problem was scabies, which caused huge financial losses. Diseases referred to as pustula, ostigo and lameness, as well as stomach and lung diseases used to be diagnosed in those days as well. Different kinds of physical injuries were also common. Breeders and vets used to apply specialist treatments; however, most of them were ineffective. The greatest successes were achieved in the case of mechanical injuries and scabies.

Keywords: ancient veterinary, sheep, diseases, scabies, lung disease

Słowa kluczowe: starożytna weterynaria, owce, choroby, świerzb, choroby płuc

Owce odgrywały bardzo istotną rolę w gospodarce państw starożytnych ${ }^{1}$, w tym także starożytnego Rzymu. Wprawdzie ich mięso nie należało do najpopularniejszych ${ }^{2}$ i spożywano

1 Wool Economy in the Ancient Near East and the Aegean: From the Beginnings of Sheep Husbendary to Institutional Textile Industry, eds. C. B ren iqu e t, C. Mich el, Oxford 2014; M.L. Ry de r, Domestication, History and Breed Evolution in Sheep, [w:] Genetic Resources of Pig, Sheep and Goat, ed. K. Ma ij a la, Amsterdam 1991, s. 157-178; D.S. Ge d d e s, Mesolithic Domestic Sheep in West Mediterranean Europe, ,Journal of Archaeological Science" 1985, vol. 12, s. 25-48.

2 Ceniono jedynie mięso bardzo młodych osobników, w pracy Apicjusza De re coquinaria zawarto niewiele 
przede wszystkim mięso młodych osobników, ale hodowano je ze względu na mleko, ser, skóry oraz wełnę ${ }^{3}$. Hodowla owiec w Italii była bardzo dobrze zorganizowana, co potwierdzają zarówno wzmianki w tekstach autorów antycznych, jak i badania archeologiczne $e^{4}$.

Współcześnie wiadomo, że w gospodarstwach rzymskich trzymano kilka ras owiec: kalabryjską i apulską ${ }^{5}$ milezyjską ${ }^{6}$, a także najwyżej ocenianą - tarencką ${ }^{7}$. Znano także owce galijskie $^{8}$ oraz erytrejskie. Różniły się one wielkością, wymaganiami hodowlanymi, a także użytecznością. Niektóre rasy hodowano przede wszystkim ze względu na wełnę i skóry, inne z powodu mleka czy mięsa. Co istotne, utrzymywanie licznych stad sprzyjało pojawianiu się chorób negatywnie wpływających na opłacalność hodowli. Z tego powodu Rzymianie starali się odnaleźć przyczyny poszczególnych schorzeń, opisać ich objawy, a także odkryć leki skutecznie zwalczające infekcje oraz inwazje pasożytnicze.

Choroby owiec oraz sposoby ich leczenia opisywali poeci, hodowcy oraz lekarze weterynarii. Wśród nich najwięcej na temat owiec pisali Wergiliusz ${ }^{9}$, Kolumella ${ }^{10}$ oraz Palladiusz ${ }^{11}$. Na podstawie ich przekazów można podjąć próbę identyfikacji poszczególnych jednostek chorobowych, co pozwoli stwierdzić, z jakimi chorobami stykali się starożytni Rzymianie, a także ocenić skuteczność proponowanych przez nich terapii.

przepisów na potrawy z baraniny, zob. idem, De re coquinaria [dalej: Apic.], 6.1-3; C. Cu m ming s, Meat Consumption in Roman Britain: The Evidence from Stable Isotopes, „Theoretical Roman Archaeology Journal" 2009, vol. 1, s. 73-83.

3 M. Gle b a, From Textiles to Sheep: Investigating Wool Fibre Development in Pre-Roman Italy Using Scanning Electron Microscopy (SEM), „Journal of Archaeological Science” 2012, vol. 39, s. 3643-3661; M. Gl eb a, Textile Production in Pre-Roman Italy, Oxford 2008; M. Mac Kin no n, Production and Consumption of Animals in Roman Italy: Integrating the Zooarcheological and Textual Evidence, Portsmouth 2004; L. Ca passo, Bacteria in Two-millenia-old Cheese, and Related Epizoonoses in Roman Populations, "Journal of Infections” 2002, vol. 45, s. 122-127; M. C o r b i e r, The Ambiguous Status of Meat in Ancient Rome, „Food and Foodways. Explorations in the History and Culture of Human Nourishment" 1989, vol. 3, s. 223-264; J.M. Fray n, Sheep-Rearing and the Wool Trade in Italy During the Roman Period, Cairns 1984.

4 U.Schmölcke, D. G ross, E.A. Nikul in a, The History of Sheep Husbandry in Austria from the Neolithic to the Roman Period, „Annalen des Naturhistorisches Museum Wien, Serie A” 2018, Bd. 120, s. 101-126; A. Lasota-Moskalewska, Zwierzęta udomowione w dziejach ludzkości, Warszawa 2005, s. 94-110; M.E. Ensminger, R.O. P arker, Sheep and Goat Science, Danville 1986.

5 Marcjalis, Epigramata [dalej: Mart.Epigr.], 14.155.

6 Pliniusz, Historia Naturalis [dalej: Plin.HN.], 8.190-191.

7 Kolumella [dalej: Col.] 7.4. Starożytni Rzymianie wysoko cenili owce tarenckie ze względu na jakość runa. Uważali jednak, że jest to bardzo wymagająca rasa zarówno pod względem warunków hodowli, jak i zapotrzebowania na pokarm. Ponadto by uzyskać wysoką cenę za wełnę lub skóry, konieczne było przeprowadzanie dodatkowych zabiegów w czasie wypasu, co wymagało dużego zaangażowania ze strony hodowcy.

8 Col. 8.2.

9 Wergiliusz, Georgices [dalej: Verg.Georg.], 3.440-453.

10 Col. 7.4-5.

11 Palladiusz [dalej: Pallad.], 14.30-32. 
Hodowla owiec była niezwykle popularna i dochodowa, dlatego Rzymianie zwracali dużą uwagę na warunki, w jakich trzymano zwierzęta, paszę, jaką je karmiono, a także na pogłębianie wiedzy hodowców. Wełna, szczególnie biała, uzyskiwała bardzo wysoką cenę, stąd tak istotna dla właścicieli była odpowiednia opieka pozwalająca zapobiec uszkodzeniu runa $^{12}$. Kłopoty ze zdrowiem owiec stanowiły poważny problem, albowiem prowadziły do znaczących strat w produkcji wełny i mleka oraz w samym pogłowiu, ponieważ wiele chorób kończyło się upadkiem chorujących zwierząt. Dodatkowo w przypadku wielu jednostek chorobowych problemem była zaraźliwość, ponieważ infekcje szybko przenosiły się na kolejne osobniki, jeszcze bardziej zwiększając straty.

Na podstawie zachowanych do dziś przekazów można stwierdzić, że jedną z najczęściej diagnozowanych u owiec chorób był świerzb. Skóra zarażonych świerzbowcem zwierząt pokryta jest łuszczącymi się wykwitami zlokalizowanymi w okolicach wargi, nozdrzy i małżowiny usznej, ale można je odnaleźć także na skórze wymienia, moszny, odbytu czy okolicy nadgarstka i stępu ${ }^{13}$. W starożytności tę chorobę uznawano za bardzo groźną ze względu na straty ekonomiczne, jakie powodowała. Wełna zakażonych owiec nie nadawała się do użytku, widoczna była także duża utrata masy ciała przy normalnym żywieniu stada ${ }^{14}$. Wpływało to negatywnie na jakość produkowanego mięsa oraz mleka, wzrastały także straty wśród nowo narodzonych jagniąt, ponieważ ich masa urodzeniowa była znacznie niższa ${ }^{15}$. $Z$ tego powodu istotne było nie tylko leczenie choroby, ale przede wszystkim zapobieganie jej wystąpieniu ${ }^{16}$.

W literaturze rzymskiej wzmianki na temat świerzbu u owiec pojawiły się w I wieku w Georgikach Wergiliusza. Poeta odnotował, że choroba pojawiała się głównie w okresie srogich zim oraz przy opadach ${ }^{17}$. W kolejnych wersach zalecał mycie owiec po postrzyżynach, a także zwracał uwagę na ewentualne rany na skórze zwierzą ${ }^{18}$. Podkreślał: „aut tonsum tristi contingunt corpus amurca $\mid$ et spumas miscent argenti uiuaque sulpura | Ideasque pices et pinguis unguine ceras $\mid$ scillamque elleborosque grauis nigrumque bitumen"19.

12 W.O. Moeller, The Wool Trade of Ancient Pompeii, Leiden 1976.

13 A.H.van der B ro ek, J.F. Hu n tle y, Sheep Scab: the Disease, Pathogenesis and Control, „Journal of Comparative Pathology" 2003, vol. 128, s. 79-91; A.M. Cla rk et al., Resistance of the Sheep Scab Mite Psoroptes ovis to Propetamphos, „Veterinary Record” 1996, vol. 139, s. 451; G.I. Wils on, K. Blachut, I.H. Ro b e r t s, The Infectivity of Scabies (Mange) Mites, Psoroptes ovis (Acarina: Psoroptidae), to Sheep in Naturally Contaminated Enclosures, „Research in Veterinary Science” 1977, vol. 22, s. 292-297.

14 A.C. Kirk wo o d, Effect of Psoroptes ovis on the Weight of Sheep, „Veterinary Record” 1980, vol, 107, s. 469470 .

15 N.D. Sargis on et al., Effect of Outbreak of Sheep Scab (Psoroptes ovis Infestation) During Mid-Pregnancy on Ewe Body Condition and Lamb Birthweight, „Veterinary Record” 1995, vol. 136, s. 287-289.

16 D. Pie d r a fi ta et al., Increased Production Through Parasite Control: Can Ancient Breeds of Sheep Teach Us New Lesson, „Trends in Parasitology” 2010, vol. 26, s. 568-573.

17 Verg. Georg. 3.440-441.

18 Ibidem, 3.442-443.

19 Ibidem, 3.447-451. 
Oprócz maści przygotowanej z wymienionych przez Wergiliusza składników skuteczną metodą walki z chorobą miało być wycięcie zarażonych miejsc i założenie opatrunku ${ }^{20}$.

Wzmianki na temat świerzbu u owiec zamieścił także w $O$ rolnictwie Kolumella. Rzymianin znał poemat Wergiliusza i opisując metody leczenia chorych zwierząt, w niektórych miejscach przytoczył wersy pochodzące właśnie z Georgik. W siódmej księdze swego agronomicznego dzieła prezentował bardzo ciekawe podejście do choroby. Autor wymienił cały szereg czynności i preparatów, których stosowanie, począwszy od chwili postrzyżyn, miało zapobiec wystąpieniu świerzbu w stadzie. Zgodnie z przekazem trzeba było zmieszać sok z gotowanego lubinu ze starym winem oraz osadem z oliwy. Tym preparatem należało natrzeć owce po postrzyżynach. Lek podawano przez trzy dni, a czwartego kąpano owce w morzu ${ }^{21}$. Kolumella podzielał także przekonania Wergiliusza dotyczące przyczyn wystąpienia świerzbu. Podobnie jak autor Georgik, wspomniał o chłodzie oraz złej pogodzie, odnotował także, że jedną z przyczyn zachorowań było niestosowanie po postrzyżynach odpowiedniego leku, który należało wcierać w skórę, oraz zaniechanie

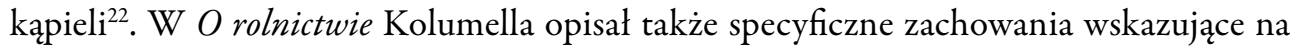
zarażenie świerzbem. Wśród nich wymienił między innymi skubanie zakażonych miejsc zębami, uderzanie w nie rogiem, tarcie o drzewa lub ściany ${ }^{23}$. Wspomniane przez Rzymianina zachowanie wynikało z dokuczliwego świądu skóry, którego przyczyną była obecność świerzbowca.

W przypadku stwierdzenia takich objawów zalecano jak najszybsze schwytanie zwierzęcia, ostrzyżenie wełny oraz zastosowanie jednego z leków opisanych w pracy. Szczególnie istotne, co podkreślał Rzymianin, było oddzielenie chorego zwierzęcia od stada ze względu na wysoką zaraźliwość, z której sprawę zdawali sobie już starożytni. Kolumella podał kilka receptur leków, które można było stosować zamiennie w zależności od składników, do jakich miało się dostęp. Pierwszy z proponowanych leków przygotowywano z równych części tłuczonej ciemiężycy białej, osadu z wina, osadu z oliwy oraz soku z gotowanego łubinu ${ }^{24}$. Skutecznym lekiem miał być także sok z zielonej cykuty zmieszany z solą, umieszczony w glinianym naczyniu i zakopany na rok, by dojrza ${ }^{25}$. Preparatem należało smarować miejsca zaatakowane przez świerzb po wcześniejszym starciu z nich strupów. Alternatywą dla wspomnianych już leków mógł być preparat przygotowany z osadu oliwnego gotowanego z ludzką uryną ${ }^{26}$. Niektóre osoby po częściowym odparowaniu samej uryny

\footnotetext{
Ibidem, 3.452-453.

21 Col. 7.4.7-8.

22 Ibidem, 7.5.5.

23 Ibidem, 7.5.6.

$24 \quad$ Ibidem, 7.5.7.

25 Ibidem, 7.5.8.

26 Ibidem, 7.5.9.
} 
dodawały do niej soku z zielonej cykuty oraz soli ${ }^{27}$. Dobry efekt miała dawać także siarka zmieszana z płynną smołą ${ }^{28}$. Kolumella, powołując się na Wergiliusza, przytoczył też najbardziej inwazyjną metodę walki ze świerzbem, czyli wycięcie chirurgiczne zaatakowanych przez chorobę miejsc.

Kilka wieków później również Palladiusz, podobnie jak Wergiliusz oraz Kolumella, zwrócił uwagę, że większa liczba zwierząt choruje w okresie występowania śniegu lub zimnych deszczy ${ }^{29}$. Jego zdaniem choroba miała się pojawiać po strzyżeniu, jeżeli nie zastosowało się odpowiednich leków oraz procedur. By zapobiec wystąpieniu świerzbu, należało umyć owce w morzu lub rzece, a także zwrócić uwagę, by zwierzęta się nie kaleczyły. Zalecano też natarcie ich skóry oliwą, co miało zapobiec wystąpieniu choroby ${ }^{30}$. Zdecydowanie odradzano umieszczanie owiec $\mathrm{w}$ pomieszczeniach wcześniej zajmowanych przez muły, konie lub osły. Pojawienie się świerzbu mogło być również wywołane brakiem paszy i wychudzeniem. W przypadku owiec choroba miała się objawiać skubaniem zmienionych chorobowo miejsc, uderzaniem w nie rogiem lub racicą, a także ocieraniem, powinny być także widoczne zmiany. Zalecano ponadto natychmiastowe odizolowanie chorych osobników od stada oraz innych zwierząt, by zapobiec szerzeniu się choroby ${ }^{31}$. Jako lek dla chorych owiec w IV wieku doradzano stosowanie mikstury sporządzonej z osadu winnego i oliwnego z dodatkiem wywaru $\mathrm{z}$ łubinu ${ }^{32}$. Za skuteczny uważano także preparat $\mathrm{z}$ soku z zielonej cykuty z uprażoną solą, którym nacierano zakażone miejsca po wcześniejszym oczyszczeniu ich szorstką cegłą lub pumeksem ${ }^{33}$. Jako lek stosowano także osad oliwny, gorącą ludzką urynę $e^{34}$, osad oliwny z sokiem zielonej cykuty i solą czy siarkę utartą z płynną smołąa $a^{35}$. Proponowano nacieranie ugotowanymi szyszkami cyprysowymi lub lekiem przygotowanym z mieszanki siarki, cibory, bieli ołowianej z masłem, niektórzy sugerowali nawet polewanie chorych zwierząt oślim moczem pozyskanym z kałuży ${ }^{36}$. Zdaniem Rzymianina część hodowców w ogóle nie stosowała leków, tylko strzygła zarażone świerzbem miejsca i przemywała je starym moczem.

27 Ibidem, 7.5.9.

28 Ibidem, 7.5.10.

29 Pallad. 14.30.1.

30 Ibidem, 14.34.1.

31 Ibidem, 14.30.3.

32 Ibidem, 14.30.5. Kilka fragmentów później Palladiusz wspomniał, żeby dodać osadu z białego wina oraz zastosować wywar z gorzkiego łubinu. Mieszankę należało podgrzać w garnku i nacierać nią owce przez dwa dni. Trzeciego dnia powinno się wykąpać owcę w morzu lub ciepłej wodzie z solą, a następnie w słodkiej (zob. ibidem, 14.34.1-2).

33 Ibidem, 14.30.6. Sok z zielonej cykuty z prażoną solą wlewano do glinianego naczynia i trzymano przez rok zakopany w gnojowisku. Lek stosowano dopiero po upływie tego czasu.

34 Ibidem, 14.30.7.

35 Ibidem, 14.30.8.

36 Ibidem, 14.34.3. 
Biorąc pod uwage przekazy Wergiliusza oraz Palladiusza, w których autorzy wspomnieli o większej liczbie zachorowań w zimie i okresach roku cechujących się zwiększoną wilgotnością, należy się zastanowić, czy część przypadków nie była błędnie diagnozowa$\mathrm{na}^{37}$. Wprawdzie świerzbowiec owczy najlepiej rozwija się w wysokiej wilgotności sięgającej nawet $85 \%$, co pokrywałoby się ze wzmiankami o większej liczbie chorych zwierząt w okresach wilgotnych, ale wymaga także stosunkowo wysokiej temperatury wynoszącej 36 stopni Celsjusza. W tych optymalnych warunkach cykl rozwojowy świerzbowca trwa 17-18 dni. W niższej temperaturze jest on znacznie wolniejszy i trwa nawet trzy miesiące ${ }^{38}$.

Rzymianie nie wiedzieli, że chorobę wywołują roztocza Psoroptes ovis ${ }^{39}$, Sarcoptes ovis, Chorioptes ovis ${ }^{40}$ oraz Psorergates ovis ${ }^{41}$, natomiast analizując przekazy autorów antycznych, widoczne staje się, że dosyć dokładnie potrafili wskazać objawy świerzbu. Co ciekawe, autorzy zachowanych tekstów weterynaryjnych byli w większości właścicielami ziemskimi nieposiadającymi wykształcenia medycznego ${ }^{42}$. Ich wiedza była efektem jedynie ich własnych obserwacji oraz informacji zapisanych przez ich poprzedników. Mimo tak nieuporządkowanej, wyrywkowej wiedzy w przypadku świerzbu zdołali odkryć mechanizm powstawania choroby oraz czynniki sprzyjające zachorowaniom. Niezwykle interesujące jest, że przekazy na temat choroby dotyczą przede wszystkim koni, bydła oraz owiec. W literaturze rzymskiej nie znajdziemy opisu świerzbu u innych gatunków zwierząt. Jest to o tyle interesujące, że choroba jest wysoko zaraźliwa i groźna nie tylko dla tych trzech wspomnianych gatunków. Chorują także świnie i kozy, o których, co niezwykle ciekawe,

37 W rozpoznaniu różnicowym pod uwagę brana jest także ospa owiec.

38 R. Wall et al., Simulation Analysis of the Population Dynamics of the Mite, Psoroptes ovis, Infesting Sheep, „Veterinary Parasitology” 1999, vol. 83, s. 253-264; A.M. Clark et al., Resistance of the Sheep Scab Mite Psoroptes ovis to Prophetampos, „Veterinary Record” 1996, vol. 139, s. 451; A.N. Sin cla i r, A.G. Ki r kw o o d, Feeding Behavior of Psoroptes ovis, „Veterinary Record” 1983, vol. 112, s. 65.

39 W.D. Smith et al., Approaches to Vaccines for Psoroptes ovis (Sheep Scab), „Research in Veterinary Science” 2001, vol. 70, s. 87-91; B.J. Losso n, J.F. Lo n n e ux, M. Leki m m e, The Pathology of Psoroptes ovis Infestation in Cattle with a Special Emphasis on Breed Difference, „Veterinary Parasitology” 1999, vol. 83, s. 219229.

40 A. Essig et al., Genetic Differentiation of Mites of the Genus Chorioptes (Acari: Psoroptidae), „Experimental \& Applied Acrology" 1999, vol. 23, s. 309-318; A.C.G. He ath, The Scrotal Mange Mite, Chorioptes Bovis (Hering, 1845) On Sheep: Seasonality, Pathogenicity and Infra-Flock Transfer, „New Zealand Veterinary Journal" 1978, vol. 26, s. 299-310.

${ }_{41}$ T. Me in tje s, L.J. Fo u ri e, I.G. Ho r ak, Host Preference of the Sheep Scab Mite, Psoroptes ovis: Short communication, „Journal of the South African Veterinary Association” 2002, vol. 73, s. 135-136; D.S. B ell et al., Psorergates ovis a Cause of Itchiness in Sheep, ,"Journal of the American Veterinary Medical Association” 1952, vol. 120, s. 117-120.

42 L. Santacroce, L. Bottalico, J.A. Charitos, Greek Medicine Practice at Ancient Rome: The Physician Molecularist Asclepiades, „Medicines (Basel)” 2017, vol. 4, s. 92; R. Jack so n, Doctors and Diseases in the Roman Empire, London 1991. 
w kontekście tej choroby nie wspomniał żaden z autorów, zaczynając od Katona, a na Wegecjuszu Renatusie kończąc.

Proponowane przez Rzymian leki w większości miały niewielkie szanse na zwalczenie ciężkich przypadków świerzbu. W celu pełnego wyleczenia zwierzęcia konieczne jest stosowanie środków z grupy awermektyn i milbemycyiny ${ }^{43}$, niemniej część używanych w starożytności preparatów miała szanse złagodzić objawy, a nawet wyleczyć lżejsze przypadki. Świerzbowiec lubi środowisko zasadowe, dlatego wszelkie preparaty o odczynie kwaśnym aplikowane miejscowo na zmiany działały świerzbobójczo. Z tego powodu leki i maści $\mathrm{z}$ dodatkiem uryny czy siarki mogły przynosić ulgę chorym zwierzętom ${ }^{44}$. Istotne w leczeniu były także preparaty na bazie ziól, na przykład pokrzywy, które ze względu na swoje właściwości łagodzące zmniejszały towarzyszący chorobie świąd. Zniesienie tego objawu było bardzo ważną kwestią, ponieważ zapobiegało drapaniu, a w konsekwencji powstawaniu ran, które mogły ulec zakażeniu bakteryjnemu, stanowiącemu groźne powikłanie choroby. Skutecznym, praktykowanym do dnia dzisiejszego sposobem walki ze świerzbem było zwiększanie higieny w pomieszczeniach dla zwierząt ${ }^{45}$.

Rzymianie oprócz będącego poważnym problemem świerzbu opisywali chorobę nazywaną przez nich pustula ${ }^{46}$. Zgodnie z obserwacją poczynioną przez Kolumellę oraz Palladiusza choroby nie dało się leczyć, ale do pewnego stopnia można ją było opóźnić, stosując okłady z koziego mleka. Ze względu na zaraźliwość choroby Kolumella i Palladiusz, powołując się na egipskiego pisarza Bolosa Mendesiusa, zalecali dokładne sprawdzanie okolic grzbietu owiec w poszukiwaniu jej śladów ${ }^{47}$. W zwalczaniu wspomnianej zarazy stosowano także zabiegi magiczne ${ }^{48}$. Jeżeli w stadzie zauważono chorą owcę, na progu owczarni wykopywano dół i zakopywano ją w nim. Resztę stada przeganiano po zasypanym dole, co miało odpędzić zarazę od stada. Biorąc pod uwagę enigmatyczne wzmianki, trudno jednoznacznie stwierdzić, która z chorób kryje się pod określeniem pustula, chociaż należałoby wziąć

43 K.Y. Mumcugolu, L. Gilaed, Treatment of Scabies Infestation, „Parasite” 2008, vol. 15, s. 248-251; D.J. O' B ri i n, Treatment of Psoroptic Mange with Reference to Epidemiology and History, ,Veterinary Parasitology" 1999, vol. 83, s. 177-185; E. Pa pad o poulo o s, G.C. F th en a kis, Administration of Moxidectin for Treatment of Sarcoptic Mange in Flock of Sheep, „Small Ruminant Research” 1999, vol. 31, s. 165168; W.M. B oy ce et al., Use of Ivermectin Implants for the Treatment of Psoroptic Scabies in Free-Ranging Bighorn Sheep, ,Journal of Zoo and Wildlife Medicine” 1992, vol. 23, s. 211-213; G.W. B e n z, R.A. Ro ncalli, S.J. Gross, Use of Ivermectin in Cattle, Sheep, Goat and Swine, [w:] Ivermectin and Abamectin, ed. W.C. Ca m p bell, New York 1989, s. 215-229.

44 Siarkę stosowano w leczeniu świerzbu zarówno u zwierząt, jak i u ludzi, zob. P.V. Gulati, K.P. Singh, A Family Based Study of the Treatment of Scabies with Benzyl Benzoate and Sulphur Oitment, „Indian Journal of Dermatology, Venerology and Leprology" 1978, vol. 44, s. 269-273.

45 T. Pęczek, Warunki zoohigieniczne a choroby owiec, „Doradca. Galicyjski Magazyn Rolniczy” 1998, t. 69, s. 17-18.

46 Col. 7.16; por. Pallad. 14.32.4.

47 Col. 7.17.

48 Pallad. 14.32.6. 
pod uwagę pryszczycę ${ }^{49}$. Wśród objawów choroby wymienia się pęcherze i nadżerki pojawiające się na błonach śluzowych oraz skórze ${ }^{50}$. Podstawowe objawy choroby korespondują ze wzmiankami na temat zmian skórnych, na które zdaniem rzymskich hodowców należało zwrócić szczególną uwagę, badając i diagnozując owce. Pryszczyca, zwana także zarazą pyska i racic, jest groźną i wysoce zakaźną chorobą zwierząt parzystokopytnych. Za jej rozwój odpowiada wirus pryszczycy Picornavirus aphtae ${ }^{51}$. Współcześnie leczenie tego schorzenia jest zabronione, a w przypadku jego stwierdzenia ubojowi interwencyjnemu poddaje się całe stado oraz wszystkie wrażliwe na chorobę zwierzęta znajdujące się w ognisku choroby ${ }^{52}$. Także Rzymianie nie podejmowali w tym przypadku prób leczenia. Uznawali, że nie ma skutecznych leków ani zabiegów chirurgicznych, wspomniane przez nich kozie mleko miało, ich zdaniem, opóźniać chorobę, nie znalazło to jednak potwierdzenia we współczesnych obserwacjach i badaniach.

Bardzo podobną, jeżeli chodzi o objawy, chorobą jest wspomniana przez Kolumellę i Palladiusza ostigo ${ }^{53}$. Obydwaj autorzy dopatrują się jej źródła w spożyciu trawy ociekającej wodą. Choroba miała być śmiertelnie niebezpieczna przede wszystkim dla jagniąt ssących mleko. Objawiała się wrzodami pojawiającymi się na pysku i wargach. Rzymianie porównywali te objawy do tych obserwowanych u zwierząt chorych na chorobę nazywaną pustula.

Objawy przypisywane ostigo sugerują, że pod tą nazwą kryje się ospa owiec wywoływana przez wirusy z rodzaju Capripoxvirus należące do rodziny Poxviridae ${ }^{54}$. Jednymi z najbardziej charakterystycznych jej objawów są wspominane już przez Kolumellę oraz Palladiusza guzki. Zmiany skórne przy ospie najpierw pojawiają się w postaci grudek, a potem pęcherzyków z płynem wysiękowym. Na początku można je zaobserwować w okolicach niepokrytych wełną, z czasem atakują inne miejsca. Zastanawiające jest łączenie przez

49 S. Alex andersen et al., The Pathogenesis and Diagnosis of Foot-and-Mouth Disease, "Journal of Comparative Pathology" 2003, vol. 129, s. 1-36; R.P. Kit ch ing, G.J. Hugh es, Clinical Variation in Foot and Mouth Disease: Sheep and Goats, „Revue Scientifique et Technique (International Office of Epizootics)” 2002, vol. 21, s. 505-512.

50 Choroby zakaźne zwierząt z elementami epidemiologii i zoonoz, red. Z. Gliński, K. Kost ro, Warszawa 2011, s. 102-105; G. Paprocka, A. Kęs y, Pryszczyca - występowanie i zwalczanie choroby, „Medycyna Weterynaryjna" 2006, t. 63, s. 251-253.

51 W. Niedbalski, A. Fitzner, Strategia DIVA w zwalczaniu pryszczycy, „Medycyna Weterynaryjna” 2017, vol. 73, s. 23-27; M.B. Mielcarska, M.D. Puchalska, F.N. Toka, Pryszczyca - nowe metody zapobiegania i zwalczania, „Życie Weterynaryjne” 2016, vol. 91, s. 88-92.

52 Dz.U. 2006 nr 28, poz. 205.

53 Col. 7.5.21; por. Pallad. 14.32.13.

54 S. Babiuk et al., Capripoxviruses: An Emerging Worldwide Threat to Sheep, Goats and Cattle, „Transboundary and Emerging Diseases" 2008, vol. 55, s. 263-272; V. B h a nu pr a k a sh et al., The Current Status of Sheep Pox Disease, „Comparative Immunology, Microbiology and Infectious Diseases” 2006, vol. 29, s. 27-60; T.V.S. Ra o, S.K. B and yo pad hy ay, A Comprehensive Review of Goat Pox and Sheep Pox and Their Diagnosis, „Animal Health Research Reviews” 2000, vol. 1, s. 127-136. 
Rzymian pojawienia się choroby ze zjedzeniem przez owce mokrej trawy ${ }^{55}$. Spożycie tego typu paszy skutkuje zazwyczaj wzdęciami, a nie zmianami skórnymi. Zbieżność między jedzeniem mokrej trawy a wystąpieniem choroby może być albo zupełnie przypadkowa, albo błędnie zidentyfikowano źródło zakażenia. Ospa owiec przenosi się drogą kropelkową, za pośrednictwem śliny czy wysięku z nosa. Biorąc pod uwagę sposoby szerzenia się zakażenia, wystarczyło jedno chore zwierzę, by przenieść wirus ${ }^{56}$.

W przypadku zdiagnozowania tej choroby Rzymianie zalecali leczenie hyzopem utartym z solą. Mieszanką nacierano podniebienie, język oraz całą okolicę pyska chorego zwierzęcia $^{57}$. Kolejną czynnością było przemycie wykwitów octem i posmarowanie ich płynną smołą zmieszaną ze świńskim łojem. Alternatywnie niektórzy wykorzystywali stary tłuszcz do smarowania osi z nalotem z miedzi. Czasem stosowano przemywanie przy użyciu utartych liści cyprysu z wodą. Metody opisane przez autorów antycznych są skuteczne o tyle, o ile minimalizowały objawy oraz zapobiegały dodatkowym zakażeniom bakteryjnym, co być może udawało się uzyskać, przemywając zmiany skórne oraz stosując maści. Także współcześnie działania lekarzy weterynarii mają na celu przede wszystkim zapobieżenie rozprzestrzenianiu się choroby, ponieważ nie opracowano skutecznych metod jej leczenia $^{58}$. Z tego powodu ich działania opierają się na leczeniu objawowym oraz zapobieganiu powstawania powikłań, podobnie jak czyniono to w starożytności.

Owce były także narażone na kulawiznę, która zdaniem Kolumelli oraz Palladiusza może powstać, gdy w szczelinie racicy powstaje owrzodzenie i odparzenie ${ }^{59}$. Chorobę wspomnianą przez Rzymian należy identyfikować ze znaną także współcześnie, nazywaną zanokcica lub kulawka, która jest wywoływana przez bakterie Dichelobacter nodosus ${ }^{60}$. W wyniku choroby tworzą się stany zapalne w przestrzeni międzypalcowej, co odpowiada zmianom opisanym przez Kolumellę oraz wspomnianym przez Palladiusza. W starożytności u chorych owiec stosowano płynną smołę, którą smarowano zaatakowane przez chorobę miejsca ${ }^{61}$.

55 Pallad. 14.32.13.

56 I. Ye r y h a m et al., Economic and Epidemiological Aspect of an Outbreak of Sheeppox in a Dairy Sheep Flock, „Veterinary Record” 2007, vol. 160, s. 236-237; R.P. Kitch ing, W.P. Taylo r, Transmission of Capripoxvirus, „Research in Veterinary Science” 1985, vol. 39, s. 196-199.

57 Col. 7.5.22.

58 W większości krajów, gdzie ospa owiec i kóz nie występuje endemicznie, nie leczy się chorych stad tylko stosuje się ubój interwencyjny. W Polsce choroba znajduje się na liście chorób wymagających zgłoszenia i zwalczanych z urzędu.

59 Col. 7.5.11; por. Pallad. 14.31.1-2.

60 W. B rzeski, Zakaźna zanokcica owiec - paronychia contagiosa ovium. Cz. 1: Zmiany kliniczne, etiologia i patogeneza, „Magazyn Weterynaryjny” 1997, t. 6, s. 18-23; i d e m, Zakaźna zanokcica owiec - paronychia contagiosa ovium. Cz. 2: Postepowanie terapeutyczne, „Magazyn Weterynaryjny” 1997, t. 6, s. 100-104; i d e m, Zakaźna zanokcica owiec - paronychia contagiosa ovium. Cz. 3: Postępowanie profilaktyczne, „Magazyn Weterynaryjny" 1997, t. 6, s. 194-196.

61 Col. 7.5.12. 
Za skuteczny uznawano także ałun zmieszany z siarką i octem lub niedojrzały granat utarty $z$ ałunem polanym octem albo posypane nalotem $z$ miedzi. Alternatywnie niedojrzały granat utarty $\mathrm{z}$ ałunem można było natrzeć spopielonymi żołędziami dębu wymieszanymi z cierpkim winem. W przypadkach, gdy w szczelinie racicy powstał wrzód, należało go usunąć chirurgicznie ${ }^{62}$. Stosowane przez starożytnych metody nie odbiegają aż tak drastycznie od działań podejmowanych przez współczesnych lekarzy weterynarii. Obecnie leczenie zanokcicy polega na usunięciu zainfekowanych części racicy, korekcji racic, odkażaniu owczarni oraz trzymaniu owiec na suchej, czystej ściółce, unikaniu wilgotnych pastwisk ${ }^{63}$ i stosowaniu odkażających kąpieli racic $^{64}$.

Rzymianie wspomnieli także o przypadkach problemów żołądkowych u owiec, które spożyły rdest ptasi ${ }^{65}$.Zdaniem Kolumelli po zjedzeniu tej rośliny owce ulegały wzdęciu, toczyły pianę z jamy ustnej oraz wydalały wodniste odchody o przykrym zapachu. Przytoczone objawy mogą sugerować wystąpienie zatrucia lub wyjątkowo uporczywych wzdęć. Zastanawiające jest, że za przyczynę choroby uznano właśnie rdest, który nie ma właściwości trujących $^{66}$. Pospolicie występuje jako chwast w uprawach i na łąkach, tak więc był zjadany przez owce. Współcześnie wiadomo, że roślina nie powoduje uszczerbku na zdrowiu, jednakże może wpływać niekorzystnie na jakość mleka, nadając mu niebieskawe zabarwienie. W przypadku wystąpienia wspomnianych objawów Rzymianie zalecali upuszczanie krwi pod ogonem oraz na górnej wardze ${ }^{67}$. Leczenie proponowane przez antycznych nie miało szansy powodzenia przy zatruciu, nie było także skuteczne w przypadku wzdęć, ponieważ w takiej sytuacji najistotniejsze było upuszczenie gazów.

Znacznie trudniejsza do identyfikacji była choroba płuc, która zgodnie z przekazem Kolumelli miała atakować przede wszystkim latem, gdy zwierzętom zabrakło wody ${ }^{68}$. W przekazach Rzymian poza nazwą choroby oraz proponowanymi kuracjami nie odno-

62 Ibidem, 7.5.13.

${ }^{63}$ P. Żmuda, Ocena przydatności wybranych sposobów postępowania w leczeniu zakaźnej zanokcicy owiec w praktyce terenowej, „Annales Universitatis Mariae Curie-Skłodowska. Sectio DD: Medicina Veterinaria” 2001, t. 56, s. 95-102.

64 W. B rzeski et al., Zastosowanie w profilaktyce zakaźnej zanokcicy owiec roztworów formaliny, Incozanu i Mastycydu jako środków miejscowo oddziatujacych, „Annales Universitatis Mariae Curie-Skłodowska. Sectio DD: Medicina Veterinaria” 1996, t. 51, s. 41-47; W. Brzeski, A. Depta, M. Bronicki, Próba leczenia zanokcicy owiec przy użciu tlenku cynku, „Acta Academiae Agriculturae ac Technicae Olstenensis. Veterinaria" 1990 , t. 19, s. 23-28.

65 Col. 7.5.19.

66 Wśród roślin faktycznie trujących dla owiec należy wymienić jaskry, wilczomlecz sosnka, skrzyp błotny oraz ziemowit jesienny. Spożycie ziemowita oraz wilczomlecza sosnka powodowało, że mleko owiec było trujące dla ludzi, zob. E. Simińska, H. Bernacka, M. Grabowicz, Ziota w żywieniu zwierząt z uwzględnieniem owiec, „Zootechnika Zootechnik” 2009, t. 37, s. 89-97.

67 Ibidem, 7.5.19.

68 Ibidem, 7.5.14. 
towano więcej informacji na temat objawów. Proponowane sposoby leczenia, zaczynając od na poły magicznego stosowania wetkniętego w ucho korzonka rośliny nazywanej consiliago $0^{69}$, po podawanie do picia octu połączonego z wlewaniem do nozdrzy ciepłej starej ludzkiej uryny i wkładanie do gardła starego tłuszczu do smarowania osi ${ }^{70}$, także nie ułatwiają identyfikacji choroby. Kolumella wspomniał o chorych płucach, tak więc w grę wchodzi jedna z licznych chorób narządu oddechowego, na przykład postępowe zapalenie płuc wywoływane przez wirus maedi-visna ${ }^{71}$ czy gruczolakowatość płuc owiec nazywana też adenomatozą ${ }^{72}$. Pierwsza z chorób charakteryzuje się zapaleniem płuc, apatią, spadkiem masy ciała, narastającą dusznością oraz stuprocentową śmiertelnością. Druga jest zakaźną, przewlekłą chorobą płuc przebiegającą z postępującą proliferacją nabłonka pęcherzyków i oskrzeli ${ }^{73}$. Choroba zazwyczaj jest połączona z dusznością i wychudzeniem, śmierć następuje z powodu ogólnego wyniszczenia. Czasem może się pojawić postać subkliniczna. Biorąc pod uwagę, że Rzymianie odnieśli się jedynie do choroby płuc, nie wspominając o wysokiej śmiertelności, bardziej prawdopodobne jest, że mieli do czynienia z gruczolakowatością płuc owiec, ewentualnie za chorobę płuc błędnie uznawano inne schorzenia, którym równocześnie towarzyszyły objawy ze strony płuc.

Kolumella uważał także, że latem problemem mogła być żółć oraz żółtaczka ${ }^{74}$, wspominał również o śluzie charakteryzującym się brzydkim zapachem. Uwzględniając przytoczone wzmianki - szczególnie lato jako okres zachorowań oraz choroby, na które zapadają owce, można założyć, że wspomnianą w tekście żółtaczkę należy traktować jako objaw gorączki doliny Rift ${ }^{75}$ lub leptospirozę $e^{76}$. Gorączka doliny Rift jest wysoce zaraźliwa i charakteryzuje się występowaniem wysokiej gorączki, śluzowo-ropnego wycieku z nozdrzy, osłabienia,

69 Ibidem, 7.5.14.

70 Ibidem, 7.5.15.

71 A. Jakuszew et al., Wirus maedi-visna $(M V V)$ w stadach owiec - zagrożenie i skala problemu, „Przegląd Hodowlany" 2010, t. 9, s. 22-26; A. Kę z zio r a et al., Podatność owiec różnych genotypów na zakażenie wirusem maedi-visna, „Medycyna Weterynaryjna” 2005, t. 61, s. 943-945; P. Kołodzi ej, S. Klimentowski, K. Rypula, Epizootiologiczne aspekty występowania choroby Maedi/Visna u owiec, „Medycyna Weterynaryjna" 1995, t. 51, s. 389-393.

72 Z. Baczyński, Adenomatoza ptuc owiec - gruczolakowatość, „Medycyna Weterynaryjna” 1983, t. 39, s. 542-546; A. Kopcze wski et al., Obserwacje nad przebiegiem adenomatozy ptuc u owiec, „Medycyna Weterynaryjna" 1979, t. 35, s. 347-349.

73 Z. Gliński, K. Kostro, Gruczolakowatość ptuc owiec, „Życie Weterynaryjne” 2009, t. 84, s. 300-303.

74 Col. 7.5.18.

75 Z. Gliński, K. Kostro, Gorązka Doliny Rift, „Życie Weterynaryjne” 2009, t. 84, s. 885-888; iidem, Czy goraczka doliny Rift zagraża hodowli owiec i bydta w Europie?, „Hodowca Bydła” 2015, t. 11, s. 68-70; G.H. Gerdes, Rift Valley Fever, „Revue Scientifique et Technique (International Office of Epizootics)” 2004, vol. 23, s. 613-623.

76 Z. Gliński, K. Kostro, Leptospiroza - groźna choroba zwierząt i zoonoza, „Życie Weterynaryjne” 2013, t. 88, s. 835-841; M. K r aw c z y k, Leptospiroza owiec na podstawie badań serologicznych, „Medycyna Weterynaryjna" 1999, t. 55, s. 397-399. 
biegunki oraz żółtaczki. Istotne jest także, że najwięcej zachorowań odnotowuje się właśnie latem. Problematyczne jest natomiast występowanie tej choroby, ponieważ zalicza się ją do tak zwanych chorób egzotycznych, które nie pojawiają się w Europie. Ze względu na występowanie bardziej prawdopodobna wydaje się leptospiroza - choroba przebiegająca z gorączką, żółtaczką, owrzodzeniem błony śluzowej, zaburzeniami trawiennymi oraz biegunką ${ }^{77}$.

Palladiusz wspomniał także, że żółć oraz żółtaczkę można usunąć, pojąc owcę ludzkim moczem ${ }^{78}$. Odniesienie się do zagrożenia, jakie może stanowić żółć w okresie letnim, wiąże się prawdopodobnie z przeniesieniem teorii humoralnej znanej w medycynie od czasów Hipokratesa ${ }^{79}$ na grunt medycyny weterynaryjnej. Odnotowana w Traktacie o rolnictwie żółtaczka w przypadku owiec stanowi jeden z objawów wielu chorób, w tym wspominanej już leptospirozy. Niemniej niezależnie od tego, jakiej z chorób towarzyszyła, ludzki mocz nie był w stanie jej łagodzić ani tym bardziej zwalczać.

Rzymscy hodowcy, gdy chorobie towarzyszył śluz o nieprzyjemnym zapachu, zalecali wkładanie do nozdrzy owiniętych wełną łodyg lebiodki pospolitej lub dzikiej mięty. Łodygi obracano w nozdrzach zwierzęcia, póki owca nie kichnęła ${ }^{80}$. Obecność śluzu w nozdrzach sugerowała jakiś rodzaj infekcji górnych dróg oddechowych. Niestety w tym przypadku Palladiusz odniósł się jedynie do tego konkretnego objawu, tłumacząc, jak radzili sobie z nim hodowcy. Nie podał innych objawów, w związku z czym trudno mówić o jakiejkolwiek konkretnej chorobie. Można zakładać, że działanie odnotowane w Traktacie o rolnictwie zalecano zawsze w przypadku pojawienia się w nosie śluzu. Wspomniany objaw towarzyszy wielu diagnozowanym u owiec jednostkom chorobowym, tak więc sam nie może stanowić podstawy do jej identyfikacji.

Hodowcy radzili sobie także z różnego rodzaju urazami. Problemem były przede wszystkim urazy kończyn, szczególnie złamania ${ }^{81}$. Leczono je w taki sam sposób jak złamania u ludzi, owijając wełną nasączoną oliwą z winem. Nogę zwierzęcia, po owinięciu wełną, umieszczano w łupkach i obwiązywano ${ }^{82}$. Stosowana przez antycznych metoda może być uznana za skuteczną w przypadku prostych, nieskomplikowanych złamań i urazów. Współcześnie w dużych stadach hodowlanych ze względów ekonomicznych rzadko podejmuje się leczenie zwierząt z tego typu urazami, są kierowane zwykle na ubój z konieczności.

\footnotetext{
77 W. Lilen b a u m et al., Detection of Leptospira spp. in Semen and Vaginal Fluids on Goats and Sheep by Polymerase Chain Reaction, „Theriogeneology” 2008, vol. 69, s. 837-842.

78 Pallad. 14.32.7.

79 W. Balzer, A. Eleftheriadis, A Reconstruction of the Hippocratic Humoral Theory of Health, „Journal of General Philosophy of Science" 1991, vol. 22, s. 207-227; A. Eleft he riad is, Die Struktur der hippokratischen Theorie der Medizin. Logischer Aufbau und dynamische Entwicklung der Humoral-Pathologie, Frankfurt 1991.

80 Pallad. 14.32.8.

$81 \quad$ Col. 7.5.18.

82 Ibidem.
} 
Hodowla owiec w starożytnym Rzymie stała na bardzo wysokim poziomie. Właściciele i hodowcy podejmowali świadome decyzje dotyczące rozrodu, rozmieszczenia budynków oraz diety. W ten sposób starano się zwiększyć zyski płynące z hodowli. Niezwykle ważna, a może najważniejsza, była umiejętność rozpoznawania chorób tych zwierząt. Zachorowania w obrębie stad powodowały olbrzymie straty, ponieważ wiele spośród nich było wysoce zaraźliwe. Rzymianie nauczyli się identyfikować wiele jednostek chorobowych, podejmowali także działania zapobiegające ich rozprzestrzenianiu się lub wręcz ich wystąpieniu. Zdecydowanie najlepiej radzili sobie ze zwalczaniem chorób pasożytniczych - szczególnie świerzbu oraz różnego typu niewielkich urazów. Stosowane przez nich leki oraz procedury dawały dużą szansę na wyleczenie chorych zwierząt. Niemniej większość chorób wywoływanych przez bakterie oraz toksyny była w antyku śmiertelnie niebezpieczna i powodowała ogromne straty, ponieważ żaden ze stosowanych wówczas leków nie był w stanie zwalczyć tych infekcji czy zatruć. Zresztą wielu ze znanych już w starożytności chorób do dnia dzisiejszego nie potrafimy efektywnie leczyć. Jedynymi skutecznymi metodami walki z nimi jest ograniczenie rozprzestrzeniania się zarazy przez ubój sanitarny lub szereg systematycznych działań profilaktycznych mających uniemożliwić wystąpienie choroby.

\section{BIBLIOGRAFIA}

Alexandersen S. et al., The Pathogenesis and Diagnosis of Foot-and-Mouth Disease, „Journal of Comparative Pathology" 2003, vol. 129, s. 1-36, https://doi.org/10.1016/S0021-9975(03)00041-0.

Babiuk S. et al., Capripoxviruses: An Emerging Worldwide Threat to Sheep, Goats and Cattle, „Transboundary and Emerging Diseases” 2008, vol. 55, s. 263-272, https://doi.org/ 10.1111/j.1865-1682.2008.01043.x.

Baczyński Z., Adenomatoza ptuc owiec - gruczolakowatość, „Medycyna Weterynaryjna” 1983, t. 39, s. 542-546.

Balzer W., Eleftheriadis A., A Reconstruction of the Hippocratic Humoral Theory of Health, "Journal of General Philosophy of Science" 1991, vol. 22, s. 207-227, https://doi.org/10.1007/ BF01801207.

Bell D.S. et al., Psorergates ovis a Cause of Itchiness in Sheep, "Journal of the American Veterinary Medical Association” 1952, vol. 120, s. 117-120.

Benz G.W., Roncalli R.A., Gross S.J., Use of Ivermectin in Cattle, Sheep, Goats and Swine, [w:] Ivermectin and Abamectin, ed. W.C. Campbell, New York 1989, s. 215-229, https://doi. org/10.1007/978-1-4612-3626-9_15.

Bhanuprakash V. et al., The Current Status of Sheep Pox Disease, „Comparative Immunology, Microbiology and Infectious Diseases” 2006, vol. 29, s. 27-60, https://doi.org/10.1016/ j.cimid.2005.12.001.

Boyce W.M. et al., Use of Ivermectin Implants for the Treatment of Psoroptic Scabies in Free-Ranging Bighorn Sheep, „Journal of Zoo and Wildlife Medicine” 1992, vol. 23, s. 211-213. 
Brzeski W. et al., Zastosowanie w profilaktyce zakaźnej zanokcicy owiec roztworów formaliny, Incozanu i Mastycydu jako środków miejscowo oddziatujących, „Annales Universitatis Mariae Curie-Skłodowska. Sectio DD: Medicina Veterinaria” 1996, t. 51, s. 41-47.

Brzeski W., Depta A., Bronicki M., Próba leczenia zanokcicy owiec przy użyciu tlenku cynku, „Acta Academiae Agriculturae ac Technicae Olstenensis. Veterinaria”, 1990, t. 19, s. 23-28.

Brzeski W., Zakaźna zanokcica owiec - paronychia contagiosa ovium. Cz. 1: Zmiany kliniczne, etiologia i patogeneza, „Magazyn Weterynaryjny” 1997, t. 6, s. 18-23.

Brzeski W., Zakaźna zanokcica owiec - paronychia contagiosa ovium. Cz. 2: Postępowanie terapeutyczne, „Magazyn Weterynaryjny” 1997, t. 6, s. 100-104.

Brzeski W., Zakaźna zanokcica owiec - paronychia contagiosa ovium. Cz. 3: Postępowanie profilaktyczne, „Magazyn Weterynaryjny” 1997, t. 6, s. 194-196.

Capasso L., Bacteria in Two-millenia-old Cheese, and Related Epizoonoses in Roman Populations, „Journal of Infections” 2002, vol. 45, s. 122-127, https://doi.org/10.1053/jinf.2002.0996.

Choroby zakaźne zwierząt z elementami epidemiologii i zoonoz, red. Z. Gliński, K. Kostro, Warszawa 2011.

Clark A.M. et al., Resistance of the Sheep Scab Mite Psoroptes ovis to Propetamphos, „Veterinary Record" 1996, vol. 139, s. 451.

Corbier M., The Ambiguous Status of Meat in Ancient Rome, „Food and Foodways. Explorations in the History and Culture of Human Nourishment" 1989, vol. 3, s. 223-264, https://doi.org/ 10.1080/07409710.1989.9961951.

Cummings C., Meat Consumption in Roman Britain: The Evidence from Stable Isotopes, „Theoretical Roman Archaeology Journal” 2009, vol. 1, s. 73-83, http://doi.org/10.16995/ TRAC2008_73_83.

Eleftheriadis A., Die Struktur der hippokratischen Theorie der Medizin. Logischer Aufbau und dynamische Entwicklung der Humoralpathologie, Frankfurt 1991.

Ensminger M.E., Parker R.O., Sheep and Goat Science, Danville 1986.

Essig A.etal., Genetic Differentiation of Mites of the Genus Chorioptes (Acari:Psoroptidae), „Experimental \& Applied Acrology" 1999, vol. 23, s. 309-318, https://doi.org/10.1023/A:1006131402463.

Frayn J.M., Sheep-Rearing and the Wool Trade in Italy During the Roman Period, Cairns 1984.

Geddes D.S., Mesolithic Domestic Sheep in West Mediterranean Europe, "Journal of Archaeological Science” 1985, vol. 12, s. 25-48, https://doi.org/10.1016/0305-4403(85)90013-5.

Gerdes G.H., Rift Valley Fever, „Revue Scientifique et Technique (International Office of Epizootics)" 2004, vol. 23, s. 613-623, https://doi.org/10.20506/rst.23.2.1500.

Gleba M., From Textiles to Sheep: Investigating Wool Fibre Development in Pre-Roman Italy Using Scanning Electron Microscopy (SEM), ,Journal of Archaeological Science” 2012, vol. 39, s. 3643 3661, https://doi.org/10.1016/j.jas.2012.06.021.

Gleba M., Textile Production in Pre-Roman Italy, Oxford 2008.

Gliński Z., Kostro K., Gorączka Doliny Rift, „Życie Weterynaryjne” 2009, t. 84, s. 885-888.

Gliński Z., Kostro K., Czy goraczka doliny Rift zagraża hodowli owiec i bydta w Europie?, „Hodowca Bydła” 2015, vol. 11, s. 68-70.

Gliński Z., Kostro K., Gruczolakowatość ptuc owiec, „Życie Weterynaryjne” 2009, t. 84, s. 300-303.

Gliński Z., Kostro K., Leptospiroza - groźna choroba zwierząt i zoonoza, „Życie Weterynaryjne” 2013, t. 88, s. 835-841.

Gulati P.V., Singh K.P., A Family Based Study of the Treatment of Scabies with Benzyl Benzoate and Sulphur Oitment, „Indian Journal of Dermatology, Venerology and Leprology” 1978, vol. 44, s. 269-273. 
Heath A.C.G., The Scrotal Mange Mite, Chorioptes Bovis (Hering, 1845) on Sheep: Seasonality, Pathogenicity and Infra-Flock Transfer, „New Zealand Veterinary Journal” 1978, vol. 26, s. 299-310, https://doi.org/10.1080/00480169.1978.34576.

Jackson R., Doctors and Diseases in the Roman Empire, London 1991.

Jakuszew A. [et al.], Wirus maedi-visna $(M V V)$ w stadach owiec-zagrożenie i skala problemu, „Przegląd Hodowlany" 2010, t. 9, s. 22-26.

Kędziora A. et al., Podatność owiec różnych genotypów na zakażenie wirusem maedi-visna, „Medycyna Weterynaryjna” 2005, t. 61, s. 943-945.

Kirkwood A.C., Effect of Psoroptes Ovis on the Weight of Sheep, „Veterinary Record” 1980, vol. 107, s. 469-470, https://doi.org/10.1136/vr.107.20.469.

Kitching R.P., Hughes G.J., Clinical Variation in Foot and Mouth Disease: Sheep and Goats, „Revue Scientifique et Technique (International Office of Epizootics)" 2002, vol. 21, s. 505-512, https://doi.org/10.20506/rst.21.3.1342.

Kitching R.P., Taylor W.P., Transmission of capripoxvirus, „Research in Veterinary Science” 1985, vol. 39, s. 196-199, https://doi.org/10.1016/S0034-5288(18)31744-2.

Kołodziej P., Klimentowski S., Rypula K., Epizootiologiczne aspekty wystepowania choroby Maedi/ Visna u owiec, „Medycyna Weterynaryjna” 1995, t. 51, s. 389-393.

Kopczewski A. et al., Obserwacje nad przebiegiem adenomatozy ptuc u owiec, „Medycyna Weterynaryjna” 1979 , t. 35, s. 347-349.

Krawczyk M., Leptospiroza owiec na podstawie badań serologicznych, „Medycyna Weterynaryjna” 1999, t. 55, s. 397-399.

Lasota-Moskalewska A., Zwierzęta udomowione w dziejach ludzkości, Warszawa 2005.

Lilenbaum W. et al., Detection of Leptospira spp. in Semen and Vaginal Fluids on Goats and Sheep by Polymerase Chain Reaction, „Theriogeneology” 2008, vol. 69, s. 837-842, https://doi.org/ 10.1016/j.theriogenology.2007.10.027.

Losson B.J., Lonneux J.F., Lekimme M., The Pathology of Psoroptes ovis Infestation in Cattle with a Special Emphasis on Breed Difference, „Veterinary Parasitology” 1999, vol. 83, s. 219-229, https://doi.org/10.1016/S0304-4017(99)00059-X.

MacKinnon M., Production and Consumption of Animals in Roman Italy: Integrating the Zooarcheological and Textual Evidence, Portsmouth 2004.

Meintjes T., Fourie L.J., Horak I.G., Host Preference of the Sheep Scab Mite, Psoroptes ovis: Short communication, "Journal of the South African Veterinary Association” 2002, vol. 73, s. 135-136, https://doi.org/10.4102/jsava.v73i3.577.

Mielcarska M.B., Puchalska M.D., Toka F.N., Pryszczyca - nowe metody zapobiegania i zwalczania, „Życie Weterynaryjne” 2016, vol. 91, s. 88-92.

Moeller W.O., The Wool Trade of Ancient Pompeii, Leiden 1976.

Mumcugolu K.Y., Gilaed L., Treatment of Scabies Infestation, „Parasite” 2008, vol. 15, s. 248-251, https://doi.org/10.1051/parasite/2008153248.

Niedbalski W., Fitzner A., Strategia DIVA w zwalczaniu pryszczycy, „Medycyna Weterynaryjna” 2017, t. 73, s. 23-27, https://doi.org/10.21521/mw.5628.

O'Brien D.J., Treatment of Psoroptic Mange with Reference to Epidemiology and History, „Veterinary Parasitology" 1999, vol. 83, s. 177-185, https://doi.org/10.1016/S0304-4017(99) 00056-4.

Papadopouloos E., Fthenakis G.C., Administration of Moxidectin for Treatment of Sarcoptic Mange in a Flock of Sheep, „Small Ruminant Research” 1999, vol. 31, s. 165-168, https://doi. org/10.1016/S0921-4488(98)00131-X. 
Paprocka G., Kęsy A., Pryszczyca - występowanie i zwalczanie choroby, „Medycyna Weterynaryjna” 2006, t. 63, s. 251-253.

Pęczek T., Warunki zoohigieniczne a choroby owiec, „Doradca. Galicyjski Magazyn Rolniczy” 1998, vol. 69, s. 17-18.

Piedrafita D. [et al.], Increased Production Through Parasite Control: Can Ancient Breeds of Sheep Teach Us New Lesson, „Trends in Parasitology” 2010, vol. 26, s. 568-573, https://doi.org/ 10.1016/j.pt.2010.08.002.

Rao T.V.S., Bandyopadhyay S.K., A Comprehensive Review of Goat Pox and Sheep Pox and Their Diagnosis, „Animal Health Research Reviews” 2000, vol. 1, s. 127-136, https://doi.org/10.1017/ S1466252300000116.

Ryder M.L., Domestication, History and Breed Evolution in Sheep, [w:] Genetic Resources of Pig, Sheep and Goat, ed. K. Maijala, Amsterdam 1991, s. 157-178.

Santacroce L., Bottalico L., Charitos J.A., Greek Medicine Practice at Ancient Rome: The Physician Molecularist Asclepiades, „Medicines (Basel)” 2017, vol. 4, s. 92, https://doi.org/10.3390/ medicines4040092.

Sargison N.D. et al., Effect of an Outbreak of Sheep Scab (Psoroptes ovis Infestation) During MidPregnancy on Ewe Body Condition and Lamb Birthweight, „Veterinary Record” 1995, vol. 136, s. 287-289, https://doi.org/10.1136/vr.136.12.287.

Schmölcke U., Gross D., Nikulina E.A., The History of Sheep Husbandry in Austria from the Neolithic to the Roman Period, „Annalen des Naturhistorisches Museum Wien, Serie A” 2018, Bd. 120, s. 101-126.

Simińska E., Bernacka H., Grabowicz M., Ziota w żywieniu zwierząt z uwzględnieniem owiec, „Zootechnika” 2009, t. 37, s. 89-97.

Sinclair A.N., Kirkwood A.G., Feeding Behavior of Psoroptes ovis, „Veterinary Record” 1983, vol. 112, s. 65, https://doi.org/10.1136/vr.112.3.65-a.

Smith W.D. [et al.], Approaches to Vaccines for Psoroptes ovis (Sheep Scab), „Research in Veterinary

Science" 2001, vol. 70, s. 87-91, https://doi.org/10.1053/rvsc.2000.0427.

Van der Broek A.H., Huntley J.F., Sheep Scab: the Disease, Pathogenesis and Control, "Journal of Comparative Pathology" 2003, vol. 128, s. 79-91, https://doi.org/10.1053/jcpa.2002.0627.

Wall R. et al., Simulation Analysis of the Population Dynamics of the Mite, Psoroptes ovis, Infesting Sheep, „Veterinary Parasitology” 1999, vol. 83, s. 253-264, https://doi.org/10.1016/ S0304-4017(99)00062-X.

Wilson G.I., Blachut K., Roberts I.H., The Infectivity of Scabies (Mange) Mites, Psoroptes ovis (Acarina: Psoroptidae), to Sheep in Naturally Contaminated Enclosures, „Research in Veterinary Science" 1977, vol. 22, s. 292-297, https://doi.org/10.1016/S0034-5288(18)33250-8.

Wool Economy in the Ancient Near East and the Aegean: From the Beginnings of Sheep Husbendary to Institutional Textile Industry, eds. C. Breniquet, C. Michel, Oxford 2014.

Yeryham I. et al., Economic and Epidemiological Aspects of an Outbreak of Sheeppox in a Dairy Sheep Flock, „Veterinary Record” 2007, vol. 160, s. 236-237, https://doi.org/10.1136/vr.160.7.236.

Żmuda P., Ocena przydatności wybranych sposobów postępowania w leczeniu zakaźnej zanokcicy owiec w praktyce terenowej, „Annales Universitatis Mariae Curie-Skłodowska: Sectio DD: Medicina Veterinaria” 2001, vol. 56, s. 95-102. 